\title{
RETHINKING ASSIGNABILITY
}

ABSTRACT: When should a contractual right be assignable to a non-party? English law's answer to this question is complex, and many of its rules are difficult to justify. In some respects, the law appears unreasonably proassignment, whereas sometimes it denies assignability to rights that should be assignable. This article contends that, in developing the law of assignability, the judiciary and Parliament have relied on a series of dubious ideas that deviate from the law's usual approach to contracts, and the current law rests partly on intuitive policy rationales that do not withstand scrutiny. The main aim of the article is to propose a new framework for thinking about the law of assignability that is more closely aligned with general ideas about contract law.

KEYWORDS: Contract, Assignment, Economics, Implied Terms

\section{INTRODUCTION}

The transfer of a contractual right from a party to a non-party is a common occurrence. Transferability facilitates a host of commercial practices, including receivables financing, the creation and trading of intermediated securities, and debt collection. The main body of legal doctrine that makes transferability possible is the law of assignment. ${ }^{1}$ In recent years, a burgeoning body of doctrinal scholarship has begun the tasks of uncovering and attempting to solve its many mysteries. ${ }^{2}$ Looming large among these mysteries is assignability - when can contractual rights be assigned, and when can't they?

The main outlines of the current law of assignability of contractual rights can be quickly stated. ${ }^{3}$ First, contractual rights are generally

\footnotetext{
1 The other main body of doctrine enabling the transfer of rights created by contract is the law of negotiable instruments, which are uncontroversially transferable.

2 The most comprehensive scholarly treatment of the topic is G. Tolhurst, The Assignment of Contractual Rights, 2nd edn (Oxford 2016). Other especially significant recent contributions include G.J. Tolhurst and J.W. Carter, "Prohibitions on Assignment: A Choice to be Made" (2014) 73 C.L.J. 405; J. Edelman and S. Elliott, "Two Conceptions of Equitable Assignment" (2015) 131 L.Q.R. 228; M. Bridge, "The Nature of Assignment and Non-Assignment Clauses" (2016) 132 L.Q.R. 47.

${ }^{3}$ Useful overall summaries of the current law of assignability of contractual rights include H. Beale (gen. ed.), Chitty on Contracts, 33rd ed. (London 2016) ch. 19 (chapter ed.: A. Burrows); A. Tettenborn, "Problems in Assignment Law" in A. Burrows and E. Peel (eds.), Contract Formation and Parties (Oxford 2010).
} 
assignable ${ }^{4}$ unless, exceptionally, they are classified as "personal"; for example, the rights of a publisher against an author are assumed to be personal and hence non-assignable. ${ }^{5}$ Second, rights to payment are not considered personal and are hence assignable. ${ }^{6}$ Third, while contracting parties are officially free to agree to limit the assignability of the rights they create, clauses restricting assignment are often viewed with suspicion. Most obviously, recent legislative intervention renders many such clauses ineffective where they purport to bar transfers of rights to payment in exchange for goods and services ("receivables"). ${ }^{7}$ Fourth, some assignments are void because they are contrary to public policy. In particular, an assignment of a claim for unliquidated damages for breach of contract is only valid if the recipient has a "genuine commercial interest" in receiving the assignment; otherwise the assignment savours of maintenance and champerty. ${ }^{8}$

This article contends that each of these four of these propositions is problematic. In so doing, it draws on the persuasive work of critics of some of these particular rules. ${ }^{9}$ But many of the rules have their defenders in the academic literature, ${ }^{10}$ and the law shows only fleeting signs of improvement. This article seeks to go further than previous work by reconsidering the law of assignability from an entirely fresh economic and legal perspective. ${ }^{11} \mathrm{~A}$ fresh perspective is needed because the existing body of doctrine rests a

${ }^{4}$ Mulkerrins v PricewaterhouseCoopers [2003] UKHL 41, [2003] 1 W.L.R. 1937, at [13], per Lord Millett: "The general rule is that the benefit of a contract may be assigned to a third party without the consent of the other contracting party".

${ }^{5}$ Chitty on Contracts, para 19-056.

${ }^{6}$ Ibid.

${ }^{7}$ Business Contract Terms (Assignment of Receivables) Regulations 2018.

8 Trendtex Trading Corp. v Credit Suisse [1982] A.C. 679.

9 E.g. G. McCormack, "Debts and Non-Assignment Clauses" [2000] J.B.L. 422; G. McMeel, "The Modern Law of Assignment: Public Policy and Contractual Restrictions on Transferability" [2004] L.M.C.L.Q. 483; A. Tettenborn, "Assignment of Rights to Compensation" [2007] L.M.C.L.Q. 392.

10 See e.g. O. Akseli, "Contractual Prohibitions on Assignment of Receivables: An English and UN Perspective" [2009] J.B.L. 650; H. Beale, L. Gullifer, and S. Paterson, "A Case for Interfering with Freedom of Contract? An Empirically-Informed Study of Bans on Assignment" [2016] J.B.L. 203.

${ }^{11}$ In this respect I agree with Andrew Tettenborn's claim that "lawyers in England have never developed a coherent theory of why there should be limitations on assignment". Tettenborn, "Assignment of Rights to Compensation", p. 401. However, as will be apparent below, I do not agree with Tettenborn's framing of the issue (why assume that the question is whether there should be limitations on assignment as opposed to permissions to assign?). See section III.C below. 
whole set of faulty assumptions that provide spurious justifications for particular rules. One of these assumptions is that, as a default matter, assignability is not a term of the contract but is instead governed by extracontractual rules. ${ }^{12}$ Moreover, in seeking to formulate these extracontractual rules, many judges and scholars rely on the conceptual claim that contractual rights (or some subset of contractual rights) are "property" and that they should therefore be transferable. ${ }^{13}$ Others supporting assignability make the policy claim that economic considerations generally favour transferability over non-transferability, such that a policy in favour of assignability "go[es] to the root of freedom and sanctity of contract which are cornerstones of market based economies". ${ }^{14}$ The case law on assignment is also occasionally haunted by a recurring error of statutory interpretation whereby judges believe that the creation of statutory form of assignment makes assignable rights that would otherwise be non-assignable. ${ }^{15}$ While each of these four faulty assumptions pushes towards assignability, a fifth one - that maintenance and champerty restrict the assignability of damages claims - pulls the courts in the direction of invalidating some assignments. ${ }^{16}$ Only when these assumptions are cleared away can the law of assignability of contractual rights be put on a secure and rational footing.

To be clear, this article concerns the transfer of rights against contractual promisors. ${ }^{17}$ In a fully effective assignment, after notice is given to the promisor, the assignee is entitled to stand in the shoes of the original promisee and to bring suit against the promisor for alleged breaches of contract. The issue, then, is when a contractual promisor can be brought before a court by a non-party to answer an allegation of breach of contract. The word "assignment" is used in English law to refer not only to such transfers, but also to transactions that grant a proprietary interest in the proceeds or "fruits" of contractual performance without transferring a right to sue the promisor. ${ }^{18}$ That will be the limited effect of an assignment where,

\footnotetext{
12 Section III.A below.

13 Section III.B. below.

${ }^{14}$ Akseli, "Contractual Prohibitions", at p. 662. See section III.C below.

15 Section III.D below.

16 Section III.E below.

17 In referring to assignments as "transfers" of contractual rights in a functional way that includes both ordinary equitable and statutory assignments, I adopt the standard view, rather than Edelman and Elliott's contention that an equitable assignment nvolves the creation of a new right that encumbers the assignor's right. See Edelman and Elliott, "Two Conceptions"; compare Tolhurst, The Assignment of Contractual Rights.

18 See R. Goode, “Inalienable Rights?” (1979) 42 M.L.R. 553, 554. The line between assignments that transfer a right to sue and those that transfer only a right to the proceeds or
} 
for example, the promisor is not notified of the assignment before performing her contractual obligations. Promisors will generally be indifferent to what happens to the fruits of their contractual performance after they have performed, ${ }^{19}$ but, as explained below, they will often care very much who is able to assert rights against them. The two issues - rights to sue the promisor and entitlements to proceeds - are distinct, and this article is concerned with the effects of purported assignment on the legal position of the promisor.

The current law of assignability is in such a poor state that it is better not to start with a detailed analysis of the current rules; no coherent approach will emerge from such an exercise. The article instead proceeds as follows. Part II stands outside current doctrine and sets forth basic principles for determining when rights should be assignable. Part III identifies five assumptions or arguments present in the case law and academic literature on assignment but inconsistent with the principles established in Part II. In Part IV, the article explains some particular problems with the current law that flow from the mistaken assumptions explored in Part III.

\section{ASSIGNABILITY FROM FIRST PRINCIPLES}

To understand assignability, we need first to understand why parties to contracts might wish to make the rights they create assignable or nonassignable (section A). Having done so, we will be in a position to approach the question of what courts should do when faced with express party agreement on the issue (section B), and to think about what courts should do when the parties have made no such provision (section $\mathrm{C}$ ).

\section{A. The Parties' Competing Interests ${ }^{20}$}

Promisees naturally tend to prefer assignability. The possibility of effecting

performance is sometimes difficult to draw and was muddied to some extent during the discussion of the Court of Appeal in First Abu Dhabi Bank PJSC v BP Oil Ltd. [2018] EWCA Civ 14. See P.G. Turner, "Prohibitions on Assignment: Intellectualism v. Law" (2018) 134 L.Q.R. 532.

${ }_{19}$ But see McCormack, "Debts and Non-Assignment Clauses", at p. 438, arguing that promisors may have legitimate reasons to invalidate assignments even as between assignee and assignor.

${ }^{20}$ The discussion here is more comprehensive than previous accounts, but draws on McCormack, "Debts and Non-Assignment Clauses", pp. 424-26; P.G. Turner, "Legal Assignment of Rights of Restricted Assignability" [2008] L.M.C.L.Q. 306, 313; R. Goode, "Contractual Prohibitions Against Assignment" [2009] L.M.C.L.Q. 300, 302-03; J. Kramer, "When Should Contracts Be Assignable? An Economic Analysis" (2004) Harvard Law and Economics Discussion Paper No. 484 (available on SSRN). 
a unilateral transfer of rights expands a promisee's options and will increase the value of those rights, though the extent of that increase depends on the particular circumstances. Where the obligation is to pay money and the promisor is unwilling to perform, the promisee might wish to transfer her rights to someone else who makes it her business to collect debts. The debtcollector will not pay the promisee the full value of the debt, but will save the promisee the trouble and expense of pursuing it. Transferring the right to sue may also shield the promisee from bad publicity; an international bank that has loaned money to a struggling developing country, for example, may wish to avoid being seen to enforce the loan. Assignment will allow the bank to recover some portion of its investment while avoiding the reputational cost of squeezing a sympathetic debtor.

Further, assignability allows a promisee who wants cash now and who holds rights to future payment against her customers to use those payment rights for financing. The promisee can confer a security interest in the payment rights as a condition of receiving a loan from a non-party; she may also simply sell her rights to a non-party. As noted above, the transfer of a right to sue the promisor requires the promisor to be notified, but many promisees would prefer to keep their financing arrangements private. In such cases the funds can be obtained through non-notification invoice discounting, which confers on the financier a right to the proceeds in the promisee's hands. But where the financier is particularly concerned with the promisee's solvency or the promisee prefers the financier to chase payment, the promisor can be notified and a right to sue can be given to the financier; this kind of financing transaction is known in the trade as "factoring" and involves assignment in the fullest sense of the term.

Receivables financing is a relatively simple form of transaction, but financial markets have used assignability to create transferable assets of increasing complexity. In securitization, for example, a corporate entity is created to receive assignments of various kinds of contractual rights, which may include residential mortgages, commercial mortgages, loans, and bonds. The corporate entity then issues securities in itself to investors. Another motivation for assignment is that a promisee may wish to be able to sell some part of its business to someone else or to another member of its corporate group.

Promisors, on the other hand, will tend to oppose assignability. Other things being equal, they prefer to retain control over the identity of those who can assert contractual rights against them. Most obviously, the very nature of the promisor's contractual performance sometimes depends on the identity of the right-holder, and it could become more onerous if another 
party could be substituted at the whim of the promisee. An insurer's willingness to cover a given risk and the premiums it charges in exchange for doing so are typically calculated with reference to the risk posed by the original policy-holder; this calculation would be frustrated if, for example, a car insurance policy could simply be transferred to a riskier driver.

But even where the thing to be done is unchanged, the identity of the person to whom it is owed is often important to the promisor. For one thing, non-assignability removes the risk that the promisor will perform for the wrong party. Where, for example, a debt claim against the promisor has been validly assigned and the promisor has been notified of the assignment, payment to the promisee will not discharge the promisor's debt, exposing the promisor to the risk of having to pay twice. ${ }^{21}$ Where the promisor is a large organization, the risk of losing track of the proper payee is a major concern and will sometimes push the promisor to develop costly bureaucratic systems for keeping track of assignments. Additionally, a successful assignment of which the promisor has been notified will limit the extent to which the promisor can invoke rights of set-off of unrelated claims arising after notification. ${ }^{22}$ This may be an important consideration where the promisor and promisee are engaged in a series of mutual dealings under separate contracts.

These reasons are important, but they do not adequately explain what one judge has called "the genuine commercial interest of a party of ensuring that contractual relations are only with the person he has selected as the other party to the contract and no one else". ${ }^{23}$ To fully comprehend the significance of this interest requires an understanding of the broader context in which contracts are included, an understanding assisted by relational contract theory. ${ }^{24}$ As the relationalists point out, contractual relationships are embedded in wider relationships between the parties. ${ }^{25}$ The written contract between the parties seeks to fix many of their performance

21 William Brandt's Sons \& Co. v Dunlop Rubber Co. [1905] A.C. 454.

22 Business Computers v Anglo-African Leasing Ltd. [1977] 1 W.L.R. 578.

${ }^{23}$ Don King Productions Inc v Warren [2000] Ch 291, 319, per Lightman J.

24 The idea of a "relational contract" has recently been imported into English contract law doctrine; a term of good faith and fair dealing is now implied into certain kinds of contracts like joint ventures, distributorships, and franchise agreements. Al Nehayan v Kent [2018] EWHC 333 (Comm), [2018] 1 C.L.C. 216. To a greater or lesser extent, however, all contracts have some relational element. D. Campbell, "The Relational Constitution of Discrete Contract" in D. Campbell and P. Vincent-Jones (eds), Contract and Economic Organisation: Socio-legal Initiatives (Aldershot 1996).

25 I.R. Macneil, The New Social Contract: An Inquiry into Modern Contractual Relations (New Haven 1980). 
obligations, but a full specification of those obligations is in many cases impossible. The parties thus rely on post-contractual co-operation to modify their mutual obligations by agreement during the course of performance. For example, a party who meets unexpected difficulties in performing may seek the other party's forbearance in enforcing her rights. Whether cooperation is forthcoming will often depend on the identity of the party holding the right. The need for cooperation in light of unforeseen circumstances, then, leaves a promisor vulnerable to opportunistic behaviour by a right-holder who declines to cooperate and seeks to enforce its strict legal rights. Even if the courts attempt to prevent such opportunism, as urged by some relational contract scholars, ${ }^{26}$ a risk remains that litigation will be too expensive or that the court will fail to understand the parties' relationship. For these reasons, promisors are wise to choose their promisees carefully, and will prefer to keep legal rights out of the hands of parties not constrained by the parties' relationship or by membership in a broader network. ${ }^{27}$ This empirical story does not in itself dictate the law's response, but it explains why promisors may not wish contractual rights against them to be transferable to third parties without their approval.

The main upshot of this lengthy (but surely not exhaustive) list of pros and cons is that one cannot generalise about whether transferability or nontransferability will serve the joint interests of the parties. It depends on the circumstances. In a long-term contract, for example, the promisor might be particularly concerned to prevent assignment to a non-party. The contract's length makes it more likely that unforeseen circumstances will arise, and the written contract will be inadequate to deal with those circumstances. Equally, however, the contract's long-term nature might lead the promisee to wish to have the power to transfer the right to someone else when the promisee's plans or priorities change. From an economic standpoint, there is no general reason for the parties to favour transferability over nontransferability (or vice versa).

26 E.g. S. Macaulay, "The Real Deal and the Paper Deal: Empirical Pictures of Relationships, Complexity and the Urge for Transparent Simple Rules" (2003) 66 M.L.R. 44.

27 Cf. Turner, "Prohibitions on Assignment: Intellectualism v Law", at p. 532 ("the law presumes that obligors are indifferent as to the identity of those whom they must deal with, regarding their contractual obligations and rights" though "evidence that the counterparty's identity mattered to the obligor can rebut the presumption"). 


\section{B. Express Agreements on Assignability}

In normal circumstances, the best evidence as to what serves the parties' joint interests is their express agreement on the matter, if there is one. Clauses dealing with the assignability of rights are a standard element of many - perhaps most — written contracts. Such clauses may expressly state that one or both parties' rights will be assignable. They may prohibit assignment entirely, or prohibit it generally with exceptions for limited classes of assignees. Thus, for example, the commonly accepted standardform provisions for letters of credit, the Uniform Customs and Practice on Documentary Credits (UCP 600), provide that the right to payment under a letter of credit is not transferable in the absence of the issuing bank's express consent. ${ }^{28}$ The suite of standard form contracts most often used in the U.K. construction industry, the J.C.T., contains by default a bar on assignment ${ }^{29}$ but now also provides the parties with the option to permit the developer to assign its rights against the builder to a buyer or a tenant of the property. ${ }^{30}$ In general, contract law (in agreement with economic analysis) assumes that the parties to contracts - especially commercial partieswould only agree to a provision if it served their joint interests at the time they entered into the contract. Or, at least, the law takes the position that the parties are usually better placed to decide what serves their interests than a judge or arbitrator deciding the matter after the fact. ${ }^{31}$ In the area of assignability, as elsewhere, freedom of contract should usually prevail.

But freedom of contract does not and should not always prevail. The law recognises two basic categories of reasons not to give effect to an expressed agreement: the need to protect a party to the contract (known in the economic literature as "paternalism") and the need to protect third parties to the agreement ("externalities"). ${ }^{32}$ To take the first of these reasons first: contract terms are sometimes imposed by one party on the other rather than

${ }^{28}$ U.C.P. 600 , art. 38(a). This provision does not affect the ability to assign the proceeds of the credit. Ibid., art. 39.

29 J.C.T. Design and Build Contract, Design and Build Contract, 2016 edn. (London 2016), s. 7.1. A prior version of this provision was the subject of the litigation in Linden Gardens Ltd v Lenesta Sludge [1994] 1 A.C. 85.

30 J.C.T. Design and Build Contract, s. 7.2.

${ }^{31}$ E.g. Watford Electronics Ltd v Sanderson CFL Ltd [2001] EWCA Civ 317; [2001] 1 All ER (Comm) 696, at [55], per Chadwick L.J.: experienced commercial parties "should be taken to be the best judge on the question whether the terms of the agreement are reasonable".

32 See P. Cserne, "Freedom of Contract (and Economic Analysis)" in A. Marciano, and G.B. Ramello (eds.) Encyclopedia of Law and Economics (New York 2018). 
emerging from conscious bargaining or genuine agreement. The law accordingly makes large-scale exceptions to freedom of contract in employment and consumer cases; more rarely does the law engage in paternalism in favour of a business party. Without evidence of misrepresentation, undue influence, duress, or breach of fiduciary duty, English law only exceptionally permits a commercial party to avoid a term to which it has given its apparent assent, ${ }^{33}$ and in particular it refuses to accept any general doctrine of inequality of bargaining power ${ }^{34}$ or unconscionability. ${ }^{35}$ Still, even in a commercial case, a provision authorizing assignment might reflect the greater market power of the promisee; likewise, a contractual term prohibiting or limiting assignment may be the result of a promisor's ability to dictate the terms on a relatively less sophisticated or powerful promise. Where these circumstances are present, the law might consider making exceptions to freedom of contract to protect the weaker party.

Assessing the significance of externalities for the enforceability of assignment or non-assignment clauses requires a more explicitly economic approach. Some scholars may contend that economic reasoning is somehow foreign to the common law of contracts or that "policy reasoning" is something only for the legislature. In fact, economic arguments already permeate the law of assignability. As explained below, the case law is full of statements about the need to reconcile freedom of contract with the freedom of markets, the economic benefits of making assets alienable, and public policy concerns about "trafficking in litigation". These discussions, however, do not systematically analyse the economic considerations at stake.

In particular, in debates over non-assignment clauses, enthusiasts for markets in contractual rights often seem to give equal weight to, on the one hand, the interests of non-parties who would like to be able to acquire contractual rights, and, on the other hand, the interests of contractual promisors who have bargained for the right to veto such acquisitions. Standing alone, however, a potential assignee's desire to acquire contractual rights against someone else does not need to be accorded any independent weight in the economic calculus. That is because, so long as the promisee is able to stand up for its own interests, the third party's interest is already represented at the original bargaining table attended by the promisor and

\footnotetext{
33 The Unfair Contract Terms Act 1977, however, provides a clear example.

${ }^{34}$ See National Westminster Bank plc v Morgan [1985] A.C. 686, 708.

${ }^{35}$ See Union Eagle v Golden Achievement [1997] A.C. 514, 519.
} 
promisee. ${ }^{36}$ If making the right in question transferable would increase the value of the right, the promisee already has an incentive to bargain for an assignability clause (or, where the default position is assignability, to refuse to assent to a clause restricting assignment). For this reason, Lord BrowneWilkinson was fundamentally correct to state in Linden Gardens that there is no reason why a contractual prohibition on assignment should be held contrary to public policy. ${ }^{37}$

Admittedly, there is a much weaker but genuinely independent thirdparty interest that is not fully represented at the bargaining table between the promisor and promisee: an informational interest. ${ }^{38}$ There is nothing economically dubious about restricting assignability, but the possibility of doing so will sometimes affect the transactions of others who do wish to make their contractual rights assignable. Suppose A and B have agreed that A's contractual rights against $B$ should be assignable, while $C$ and $D$ have agreed that C's rights against D should be non-assignable. A then approaches $\mathrm{E}$ seeking to transfer its rights against $\mathrm{B}$ to $\mathrm{E}$. The problem for $\mathrm{E}$ is that he will have to discern whether A's contract with B is or is not like C's contract with D. The possibility of an effective non-assignment clause means that potential assignees must guard against the risk that the rights they are acquiring might turn out to be ineffective against the promisor. They will have to inspect the contractual agreements that create the rights they are acquiring, or increase the cost of the transaction to the promisee as compensation for this risk, or take further precautions against the risk (for example, securing a personal guarantee from the officers of a corporate promisee).

This diffuse market interest, however, is weak when it comes up against the interests of large swathes of promisors who have valid reasons to veto a change in the identity of the party able to sue them for breach of contract and who have specifically bargained for the insertion of such a clause into the contract. Moreover, the burden on prospective assignees should not be overstated; assignment clauses are easy to spot and a party considering whether to take an assignment of a contractual right will need to satisfy herself of the content of that right anyway, necessitating an inspection of the contractual documents. The proper response to the transferee's concerns about possible non-assignment clauses is that she should read the written contract that creates the rights she is acquiring before acquiring those

${ }^{36}$ See T.W. Merrill and H.E. Smith, "Optimal Standardization in the Law of Property" (2001) 110 Yale L.J. 1, 30.

${ }^{37}$ Linden Gardens, [1994] 1 A.C. 85, 107.

${ }^{38}$ See Merrill and Smith, "Optimal Standardization”, pp. 31-34. 
rights,${ }^{39}$ or take the risk that the promisor has validly bargained to prevent assignment of a right to sue.

\section{Assignability in the Absence of Party Agreement}

Assignability clauses are extremely common in written contracts. Still, the parties may not have made a provision on the issue, especially in the case of an oral agreement or a relatively short, informal written contract. If there is gap in the contract on the issue of assignability, and the validity of a purported assignment is contested, the law has to provide an answer. ${ }^{40}$

English law uses a variety of techniques to fill gaps in contracts. The easiest way to justify a gap-filling solution is to invoke the presumed intent of the parties. Courts faced with a gap in the parties' contract may ask what these particular parties have tacitly agreed to, or, more realistically, what they would have agreed to had they turned their attention to the matter; the relevant legal techniques are contractual construction and the implication of terms in fact. ${ }^{41}$ In the interests of making the law more predictable, the law may instead ask this question at a higher level of generality: what would serve the interests of parties to this class of contract in general? The result of such an inquiry is known in the economic literature as an "untailored majoritarian default"42; in English law, some terms implied in law are best understood in this way. In the specific context of assignability, predictability may be more significant than in many other contractual contexts, so it is likely to be sensible to categorize different classes of contract as either assignable by default or non-assignable by default, rather than to make that judgment on a case-by-case basis.

Aside from looking to hypothetical party agreement, the law might find other sufficiently compelling reasons for filling gaps in contracts. To the extent it departs from a judgment as to what these parties or parties more generally would have agreed, such a policy-based default can be based on the same kinds of arguments discussed above: paternalism or third-party interests. In English law, some terms implied in law fall to be justified on that basis. ${ }^{43}$ In the specific area of assignability, too, the choice of default

\footnotetext{
${ }^{39}$ That, at least, was the response of Judge Richard Posner to an assignee who claimed to have taken an assignment of a right made non-assignable by the parties. Bank of America $v$. Moglia, 330 F.3d 942 (7th Cir 2003).

40 I. Ayres and R. Gertner, "Filling Gaps in Incomplete Contracts" (1989) 99 Yale L.J. 87.

${ }^{41}$ See H. Collins, "Implied Terms: The Foundation in Good Faith and Fair Dealing" (2014) 67 C.L.P. 297.

${ }^{42}$ Ayres and Gertner, "Filling Gaps", p. 127.

${ }^{43}$ E. Peden, "Policy Concerns behind Implication of Terms in Law" (2001) 117 L.Q.R. 459.
} 
rules need not to be solely limited to trying to determine what the parties would have agreed, though in a commercial context that is usually likely to be the sensible approach.

\section{FAULTY ASSUMPTIONS UNDERLYING THE CURRENT LAW}

The previous section provides a framework for thinking about when contractual rights to sue should be assignable. In outline, the law should seek a result in line with promisor-promisee intent except where a compelling argument based on paternalism or externalities requires a different result. This section examines a series of assumptions and arguments, present to a greater or lesser degree in English law, that do not fit with this framework.

\section{A. Assignability Depends on Extracontractual Rules of Law}

One might think that the identity of the person who can sue under a contract would be considered a term of that contract - one of its most basic terms. But unless the parties have made an express provision on the issue, the rules of assignability are conceptualized not as terms but as extracontractual rules. ${ }^{44}$ Occasionally courts speak as if the availability of assignment in the absence of an express provision depends on construction or implication, ${ }^{45}$ but generally the only role of party agreement is to alter a rule superimposed on the contracting parties. The difficulty with this way of proceeding is that it avoids frank engagement with the potential clash between the contract that creates the right and the rules governing its transferability. In particular, why should a promisee generally have the unilateral power to confer a right to sue on a third party where she has not expressly bargained for such a power?

As suggested at the end of the last section, the only way to provide a justification for an assignability default in line with contract law's basic ideas is through a convincing implied term analysis. English law recognises two kinds of implied terms: terms implied in fact based on the presumed intentions of the parties to a particular contract, and terms implied by law into categories of contract. ${ }^{46}$ As Michael Bridge has pointed out, however,

\footnotetext{
${ }^{44}$ Mulkerrins v PricewaterhouseCoopers [2003] UKHL 41, [2003] 1 W.L.R. 1937, at [13], per Lord Millett.

${ }^{45}$ See Tolhurst v Associated Portland Cement Manufacturers (1900) Ltd. [1903] A.C. 414, 420, where Lord Macnaghten justified his decision in favour of assignability by saying that "the plain intention of the parties" was to allow subsequent owners of the cement business to assert rights under the contract.

${ }^{46}$ Geys v Société Générale [2012] UKSC 63, [2013] 1 A.C. 523, at [55].
} 
the current general rule of assignability is impossible to explain as a term implied in fact, ${ }^{47}$ under either the "officious bystander" or the "business efficacy" test. The parties to some contracts might suppress an officious bystander who asked them whether the rights they were creating should be transferable without the promisor's consent, but that is likely to be true in only a minority of cases. Likewise, it is only in unusual contexts that assignability is necessary to give business efficacy to the contract between the original contracting parties. The assignability default rule is plainly not based on an attempt to capture the presumed intent of the particular parties to a specific contract; only rarely can it be said that "the contract would lack commercial or practical coherence" if assignment were not possible. ${ }^{48}$ And, anyway, the assignability default is not based on the circumstances or intentions of the particular parties to the contract; it applies to large classes of contractual rights - to contractual rights in general, with the class of "personal" contractual rights exempted.

To the extent that the assignability defaults are to be considered terms of the contract between the parties, then, they must be terms implied in law or "standardized terms". ${ }^{49}$ Certainly, the fit seems much better than is the case with terms implied in fact. But can the current rules be justified in line with the law's general approach to terms implied in law? That depends in part on what the law's general approach is. A restrictive view, that has sometimes tempted the courts, is that where judicial implication of terms is concerned, a term may only be implied in law where it a necessary incident of the kind of contract concerned. ${ }^{50}$ But the current default, except in the unusual case of "personal" rights, makes little effort to distinguish among different kinds of contract, and assignability is hardly a necessary incident of contracts in general. An alternative - and more attractive - approach to the judicial implication of terms in law eschews "the elusive concept of necessity" and recognises that "the existence and scope of standardised implied terms raise questions of reasonableness, fairness and the balancing of competing policy considerations". ${ }^{51}$ This looser approach may better reflect what courts have been doing in the area of terms implied in law, ${ }^{52}$ and it certainly reflects

\footnotetext{
47 Bridge, "Non-Assignment Clauses", at p. 54.

48 See Geys [2012] UKSC 63, at [55].

49 See Malik v Bank of Credit and Commerce International S.A. [1998] A.C. 20, 45.

50 Liverpool City Council v Irwin [1977] A.C. 239, 254.

${ }^{51}$ Crossley v Faithful \& Gould Holdings Ltd [2004] EWCA Civ 293, [2004] 4 All E.R. 447.

52 Geys [2012] UKSC 63, at [56], per Lady Hale: "There is much to be said for that approach, given the way in which those terms have developed over the years".
} 
legislative practice in adding terms to contract. We will return to the supposed policy basis for preferring assignability below. For the moment, however, the point is just that, by holding that the default rules of assignability are not terms at all, the current law ignores the potential clash with the parties' contract. As Bridge notes, the law's silence concerning the existence of an implied term comes "close to an admission that assignment is not to be reconciled with contract at all". 53

\section{B. Contractual Rights are Property and Thus Assignable}

A tenacious idea in assignment law attributes independent significance to whether contractual rights are "property". The idea is that if contractual rights, or some subset of contractual rights, are labelled "property", that means they must be transferable. Much of the debate among doctrinal scholars of assignability concerns whether contract rights are or are not also property rights; the answer to this question is then thought to have consequences for the assignability of contractual rights. ${ }^{54}$

The attribution of independent significance to the conceptual classification is not just an academic practice; it has long influenced the decisions of courts. This is most obviously the case where the contractual right concerned is a claim to an agreed sum of money. Claims for agreed sums of money were vindicated at common law through the action for debt, which was historically viewed as being in some sense "proprietary". ${ }^{55}$ That did not mean the common law recognised assignment; indeed, the common law resisted assignability for centuries. But after equity facilitated assignments of debt claims, and especially after the recognition of statutory assignment, it became commonplace to say that such claims were a form of property, and to attribute assignability to the proprietary character of "choses in action". For example, in Fitzroy v. Cave it was stated that "in all Courts a debt must be regarded as a piece of property capable of legal assignment in the same sense as a bale of goods". ${ }^{56}$ This reasoning was taken to justify the extraordinary conclusion that an assignment taken for the sole purpose of bankrupting the promisor was effective. More recently, in the Camdex case, Hobhouse L.J. stated that "[d]ebts are a species of

\footnotetext{
${ }^{53}$ Bridge, "Non-Assignment Clauses", at p. 54.

${ }^{54}$ See ibid., at p. 47: "The assignment of things in action sits precariously between contract law and property law".

55 F. Pollock and W. Maitland, A History of English Law Before the Time of Edward I, Vol. II (Cambridge 1895), 204-07.

${ }^{56}$ [1905] 2 K.B. 364, 373.
} 
property recognised before 1873 in equity and since that date both in law and equity. Like other species of property they may be transferred to another and the legal rights which are incidents of that property may be exercised by the new owner of the property". ${ }^{57}$ This proprietary character of a claim to an agreed sum of money was strong enough to override any concerns about champerty and maintenance that would otherwise have endangered the assignment in Camdex. Again, in Barbados Trust $v$ Bank of Zambia, discussed below, the Court of Appeal framed the question as one concerning whether the contested clause was "an attempt to place fetters on the unencumbered property of an individual" 58 and one judge stated that "since one is concerned with the question whether a restriction should be placed on the transfer of a piece of property, an acknowledged debt, the court should be slow to contemplate that the parties ever intended such to be within the prohibition". 59

These statements have it backwards. They assume that a certain class of rights are "property" and should therefore be transferable. But what matters is when contractual rights are transferable. Once we have figured that out, we will then be able to decide whether and when, for this particular purpose, it is appropriate in this limited sense to say that some contractual rights are being treated like (most forms of) property. Or, if designating a right as "property" necessarily makes it transferable, then contractual rights should (sometimes) not be designated property rights.

\section{Economic Considerations Favour Assignability in General}

Though the idea that contractual rights (or, more narrowly, debt claims) are property and hence assignable is sometimes taken seriously on its own terms, it is often meant to express an instrumental or policy justification in favour of assignability. ${ }^{60}$ In particular, in the case of real property, legal rules sometimes invalidate contractual restrictions on alienation. The argument that contractual rights are property may then be taken as a claim that analogous public policy considerations require them to be transferable.

\footnotetext{
57 Camdex International Ltd. v Bank of Zambia (No. 1) [1998] 1 Q.B. 22.

${ }^{58}$ Barbados Trust Co. Ltd. v Bank of Zambia [2007] EWCA Civ 148, [2007] 1 C.L.C. 434, at [7].

${ }^{59}$ Ibid., at [43], per Waller L.J. See also ibid., at [88], where Rix L.J. refers to the debt as a form of "property" in the course of concluding that the right-holder could declare a trust over it.

${ }^{60}$ W. Day, "Non-Assignment Clauses-the Statutory Solution" (2019) 135 L.Q.R. 205 ("An overly-simplistic argument that contractual rights are property rights and that property rights should be capable of alienation has given way to a more refined approach".).
} 
More directly, without insisting that contractual rights are property, proponents of assignability can simply make an "argument about liquidity and cost of credit and the need for the workings of private law to foster the former and lower the latter". ${ }^{61}$ The judgment of Rix L.J. in Barbados Trust-mentioned above and discussed further below-provides a particularly clear example of the claim that public policy requires assignability. Expressing some degree of hostility to the choice of contracting parties to make contractual rights non-assignable, Rix L.J. stated that it was important that "financial assets are not too readily made inalienable especially where markets regularly provide liquidity for the trading of them". ${ }^{62}$ If the parties to contracts could decide without any limitation to prohibit assignment, "the public interest in freedom of contract and the freedom of markets could be severely prejudiced". ${ }^{63}$

A similar claim is made explicitly by Professor Goode, who notes that rules against alienation "have traditionally been directed to physical assets in general and land in particular; but in modern commerce, transactions involving physical assets are dwarfed in value by dealings in pure intangibles, particularly debts, intermediated securities and derivatives". ${ }^{64}$ Based on these practices, Professor Goode says that "[i]t is thus important that legal rules based on freedom of contract do not impair the free flow of intangibles in the stream of trade" ${ }^{65}$ Professor Goode's watery metaphor stands in direct opposition to Lord Browne-Wilkinson's claim in Linden Gardens that any policy in favour of alienability simply does not apply to contractual rights. ${ }^{66}$ In the case of land "there is a defined and limited supply of the commodity ... but no such reason can apply to contractual rights: there is no public need for a market in choses in action". ${ }^{67}$ In economic terms, as explained above, Lord Browne-Wilkinson's view is fundamentally correct. Where the parties have freely agreed to create non-assignable rights, there is no valid economic case based on externalities for making them assignable.

The assumption that economic arguments generally favour transferability is also invoked to support a default rule of assignability.

\footnotetext{
${ }^{61}$ Akseli, "Contractual Prohibitions", at p. 662.

${ }^{62}$ Barbados Trust [2007] EWCA Civ 148, at [112].

${ }^{63}$ Ibid.

${ }^{64}$ Goode, "Contractual Prohibitions", p. 300.

${ }^{65}$ Ibid.

${ }^{66}$ Linden Gardens [1994] 1 A.C. 85, 107.

${ }^{67}$ Ibid.
} 
Andrew Tettenborn, in an otherwise highly perceptive piece on the assignability of damages claims, states in support of a claim that intangible rights should be generally be assignable that "just as welfare is maximized if tangible assets end up in the hands of those who value them the most, so also with intangibles". ${ }^{68}$ This statement seem to rests on the assumption that the promisor's often-substantial reasons to avoid assignment are pervasively (rather than only sometimes) outweighed by the promisee's reasons to want it. Similarly, Tettenborn's claim that intangible rights will be "effectively sterilized" if they are inalienable pays insufficient heed to the fact that, as explained above, the value of the original contract often depends in part on the inalienability of rights arising under it. ${ }^{69}$

\section{The Difference Between Equitable and Statutory Assignments is Significant for Assignability}

English law maintains a confusing distinction between equitable and statutory (or "legal") assignments that can only be understood with reference to history. Historically, courts of common law refused to permit assignment, with limited exceptions. But courts of equity from the seventeenth century onwards took a different view, recognizing assignments of both equitable and legal rights. Where the assigned right was one recognised by the courts of common law, a court of equity would compel an unwilling assignor to bring suit in the common law courts on the assignee's behalf. ${ }^{70}$ Even before the Judicature Acts, common law courts effectively recognised assignments, permitting assignees to control litigation nominally brought by assignors. With the fusion of the administration of law and equity, assignment was made official, with the recipient of a fully valid assignment now able to sue in all courts in her own name, joining the assignor as a co-claimant (if she was willing) or as a co-defendant (if she was not).

But Parliament also made a further change, enacting section 25(6) of the Judicature Act 1873, which was later repealed and re-enacted as section 136 of the Law of Property Act 1925. The provision concerns assignments of "any debt or other legal thing in action". Where (i) the assignment is absolute, (ii) the assignment is made in writing, and (iii) the promisor has been given express notice in writing, the statute provides that the legal right

\footnotetext{
68 Tettenborn, “Assignment of Rights to Compensation”, at p. 403.

${ }^{69}$ Unlike some others, Tettenborn does not take this claim about sterilization too far; he appears to be happy for courts to enforce non-assignment clauses. Ibid., at p. 405.

70 See Hammond $v$ Messenger (1838) 9 Sim. 327, 59 E.R. 383.
} 
to the debt or other legal thing in action passes to the assignee and that the assignee is entitled to all remedies for its enforcement. The function of section 136 is to provide a mechanism that enables the assignor to drop out of the litigation entirely. The requirement of an absolute assignment (as opposed to an assignment of part of a claim) is supposed to limit statutory assignment to cases where the assignor has no interest in the dispute between the assignee and the obligor. Where the assignor retains an interest, the assignor (or, in the case of successive assignments, multiple assignors) must be named as parties, providing them with notice of the proceedings and the ability to influence them. Historically, courts have sometimes been willing to dispense with the need to join the assignor even where the assignment does not meet the statute's requirements, where joinder seems unnecessary. ${ }^{71}$ In practice, then, it makes little difference whether an assignment is statutory or equitable.

The assignability of contractual rights was not supposed to be affected by the procedural reform. ${ }^{72}$ And there is no reason of policy or principle that a right unassignable in equity should be assignable where the statutory requirements have been met. Nevertheless, there has been a long-running tendency to attribute substantive consequences to this procedural reform. The mistaken view that section 136 affects assignability appears to have crept into the judgment of Hobhouse L.J. in Camdex and to have been combined with the property error noted above: "[I]f there is a debt it is a species of property and the fact that the debtor disputes it ... does not make it any the less a debt nor does it provide a basis for failing to give effect to section 136 or its predecessor". ${ }^{73}$ Likewise, in a concluding flourish, Hobhouse L.J. discerned that "the policy of English law, and section 136, is that where debtors are in default judgment should be entered against them in favour of the owner of the debt" ${ }^{74}$ without explaining where in section 136 this policy is expressed. Most recently, in Hockin v Royal Bank of Scotland the Royal Bank of Scotland sought to argue that section 136 gave it a statutory right to assign. ${ }^{75}$ The argument was rightly rejected by the judge, ${ }^{76}$

\footnotetext{
${ }^{71}$ See Tolhurst and Carter, "Prohibitions on Assignment", p. 425 note 64.

72 Torkington v Magee [1902] 2 K.B. 427, 435, reversed on other grounds, [1903] 1 K.B 644; Tolhurst $v$ Associated Portland Cement Manufacturers (1900) Ltd [1902] 2 K.B. 660, 676-77; Tolhurst v Associated Portland Cement Manufacturers (1900) Ltd [1903] A.C. 414, 424.

${ }^{73}$ Camdex International Ltd v Bank of Zambia (No.1) [1998] Q.B. 22, 33.

${ }^{74}$ Ibid., at p. 39.

75 [2016] EWHC 925 (Ch), at [34].

${ }^{76}$ Ibid., at [44].
} 
but the fact that it was even made goes to show how tenacious the mistaken assumption is.

\section{E. Assigning Claims to Litigate is Inherently Problematic}

The four previous mistaken ideas have all tended to favour assignability, but a fifth tends to restrict it. It pops up in cases where, at the time of the assignment, it is clear that the promisor will not perform her alleged obligations without being sued. Assignments are sometimes held invalid because they involve "trafficking in litigation - a type of transaction which, under English law, is contrary to public policy". ${ }^{77}$ An assignment of a right to litigate might be thought to "savour" (i.e. taste) of maintenance (meddling in someone else's litigation) and champerty (meddling in someone else's litigation for a share for the proceeds). An assignee is thought to be somewhat like someone who funds another's litigation in exchange for a cut of the proceeds. This is so even though the assignee is suing in his own right rather than meddling in someone else's litigation. In 1967, Parliament abolished criminal and tortious liability for champerty and maintenance, but expressly preserved any rule of law as to the cases in which a contract involving maintenance or champerty is contrary to public policy or illegal. ${ }^{78}$

The law's scepticism about transferring certain causes of action is starkly at odds with the more prevalent - though also dubious - view that the transferability of contractual rights is by its nature economically beneficial. It has begun to seem especially anachronistic in light of changes to closely analogous areas of law. Lawyers may now enter into conditional fee agreements with their clients, and London now has some of the world's most liberal rules for litigation funding by parties who have no prior connection to the claim; such third parties can finance the costs of litigation in exchange for a portion of the proceeds without running afoul of the prohibition against champerty.

On closer inspection, the actual problem with champerty is supposed to be that the desire to make a profit will encourage the intermeddler to seek more damages than she is entitled to, to suppress evidence, and to suborn perjury. ${ }^{79}$ These are undoubtedly bad things. If a link between them and assignment could be established it might provide a basis for concluding, as a matter of implied intention, that the parties would not have wanted to allow assignment in such circumstances (Q: "Do you mean to authorise an activity

\footnotetext{
77 Trendtex Trading Corp. v Credit Suisse [1982] A.C. 679, 694.

${ }^{78}$ Criminal Law Act 1967, s. 14(2).

${ }^{79}$ Re Trepca Mines Ltd. (No. 2) [1963] Ch. 199, 219-20.
} 
that encourages fraud and perjury? A: Of course not!"). But, as Tettenborn points out, it is unclear is why an assignee, merely in virtue of being an assignee, is more likely to overclaim or commit fraud than the original rightholder. ${ }^{80}$ Misconduct in litigation should be punished as it arises, whether perpetrated by a contracting party or by an assignee.

The idea of "trafficking in litigation", then, does not identify a genuine problem with assignments. This point was perhaps recognised by Lady Hale when she stated, in upholding an assignment of a cause of action, that "'trafficking' is a pejorative term which takes the debate no further: it simply means trading in something (be it drugs or people) in which it is not permissible to trade" ${ }^{81}$ As we will see below, however, the idea underlies a significant portion of the law on assignability of contractual rights.

\section{PARTICULAR PROBLEMS WITH THE CURRENT LAW}

\section{A. Non-Assignment Clauses are not Adequately Respected}

In the absence of a compelling reason to the contrary, freedom of contract should prevail here as elsewhere. English law does pay lip-service to freedom of contract in assignability. ${ }^{82}$ In at least two ways, however, freedom of contract does not fully prevail. First, the courts have shown a willingness to allow a promisee seemingly bound by a non-assignment clause to evade such a clause by declaring itself a trustee of its contractual rights for a third party. Second, in the case of receivables, statutory intervention explicitly overrides freedom of contract. Each of these legal developments is partly premised on mistaken assumptions identified in Part III.

\section{A Declaration of Trust Can Seemingly Evade a Non-Assignment Clause}

The decision of the Court of Appeal in Barbados Trust v. Bank of Zambia ${ }^{83}$ has already been subject to a great deal of commentary, but its extraordinary facts merit repeating. The central bank of Zambia entered into a contract of loan whereby various international banks advanced large sums of money to finance oil imports in 1985. The relevant contract of loan included a complex assignability clause, allowing assignment in certain circumstances - but only to "banks or other financial institutions". As the

${ }^{80}$ Tettenborn, “Assignment of Rights to Compensation," at p. 403.

${ }^{81}$ Massai Aviation Services v Attorney General [2007] UKPC 12.

${ }^{82}$ Linden Gardens [1994] 1 A.C. 85, 107.

83 [2007] EWCA (Civ) 148. 
High Court judge pointed out, "[a]ny borrower, but particularly a central bank, may be concerned to ensure that its affairs and obligations are known and owed to and only enforceable by established and authorised institutions". ${ }^{84}$ Later, the debt was purportedly assigned to Bank of America, clearly a member of the permissible class of assignees. Bank of America, however, decided to offload the asset to the distressed debt market. It did not assign the loan but instead declared itself a trustee of the debt for Barbados Trust. Barbados Trust was not a bank or other financial institution. For reasons that need not concern us, the Court of Appeal concluded by a majority that the previous assignment to Bank of America was invalid, and so it became unnecessary to decide on the validity of the declaration of trust in favour of Barbados Trust.

Two members of the Court of Appeal, however, would have been prepared to hold as a matter of contractual construction that the clause restricting assignment did not cover declarations of trust. Rix L.J. and Waller L.J. concluded that if the parties had wished to bar declarations of trust in addition to assignments, they should have done so explicitly. ${ }^{85}$ Yet the same judges agreed that, as the beneficiary of a trust, Barbados Trust would have been able to bring a suit against the Bank of Zambia under the Vandepitte procedure, whereby the beneficiary of a trust can sue in her own name where the trustee is unwilling to bring suit on her behalf. ${ }^{86}$ Barbados Trust, in the majority's view, could have brought an action directly against the Bank of Zambia so long as it joined Bank of America, just as an equitable assignee could.

A declaration of trust is not quite the same thing as an equitable assignment. ${ }^{87}$ But, to the extent that the upshot of a declaration of trust is that the beneficiary can bring an action against the promisor, joining the trustee as a co-defendant, then the two things are functionally the same. ${ }^{88} \mathrm{As}$

\footnotetext{
${ }^{84}$ Ibid., at [6].

85 Ibid., at 451-52, per Waller L.J.

${ }^{86}$ Vandepitte v Preferred Accident Ins. Corp. of New York [1933] A.C. 70, 79.

${ }^{87}$ Edelman and Elliott argue that an equitable assignment is the same thing as a declaration of trust. Nevertheless, they suggest that the majority position in Barbados Trust might possibly be justified on the basis that the no-assignment clause could be construed only to apply to legal assignments. Edelman and Elliott, "Two Views", at pp. 248-49. That, however, does not seem a plausible interpretation of the clause any more than Rix L.J. and Waller L.J.'s does.

${ }^{88}$ Turner points out that, unlike an assignee who has given notice to the promisor, a trust beneficiary can only sue in exceptional circumstances, including fraud. Turner, "Prohibitions on Assignment: Intellectualism v. Law", at 535-36. But the required circumstances are not so exceptional, for they include cases in which the trustee declines to bring suit on the beneficiary's behalf.
} 
noted by the High Court judge, by Hooper L.J. in dissent on this point, and by a host of critical academic commentators, the effect of this construction was to permit the legal result that the non-assignment clause was designed to avoid-liability to suit by a party that is not a bank or financial institution. ${ }^{89}$ To conclude that a non-assignment clause does not include a declaration of trust is hardly the kind of commercial common-sense interpretation that courts are supposed to engage in nowadays.

Rather than based on a plausible construction of party intent, then, the narrowing construction given to the clause in Barbados Trust appears to have been inspired by a sense that public policy supported it. Rix L.J.'s judgment states this expressly. When discussing the all-important issue of whether the beneficiary of a trust could use the Vandepitte procedure to bring a direct suit and thereby do the precise thing that the non-assignment clause was designed to prevent, Rix L.J. referred to the tension between those who (like the Bank of Zambia) wished to decide who could sue them and two other groups to whom those interests sometimes needed to yield. First, he referred to the "interests of those who seek to arrange their affairs on the basis of holding property in trust for others" ${ }^{90}$ But people who wish to be able to transfer their rights to sue to others can protect themselves by refusing to agree to a restriction on assignment or, in the case of a transferee, by declining to purchase a right of limited assignability. Second, Rix L.J. referred to the "public interest" in alienability. ${ }^{91}$ As explained above, however, there is no general economic reason to favour alienability over inalienability.

Because it is based on the construction of a "no-assignment" clause, the Barbados Trust decision can in principle be overridden by an explicit "no trust" clause. Giving further support to the conclusion that the parties to contracts see no relevant distinction between assignments and trusts to the extent that both confer on the recipient a right to sue the promisor, such "no trust" language is apparently being inserted into non-assignment clauses now as a matter of course. ${ }^{92}$ But if, as Rix L.J.'s judgment seems to suggest, the decision is really based on public policy, courts may decline to enforce

${ }^{89}$ Barbados Trust [2007] EWCA (Civ) 148, at [129]-[143] (Hooper L.J., dissenting).

90 Ibid., at [112].

91 Ibid.

92 See, for example, the boilerplate non-assignment clause suggested in Thomson Reuters Practical Law Commercial, "Assignments and Other Dealings" (accessed 21st January 2020): "Neither party shall assign, transfer, mortgage, charge, subcontract, delegate, declare a trust over or deal in any other manner with any of its rights and obligations under this agreement". (emphasis added). 
"no trust" clauses and to allow the beneficiaries of trust to bring direct suit under the Vandepitte procedure. Such a decision to override contractual freedom would not be justified.

\section{The Receivables Regulations}

In the area of receivables - claims to payment in exchange for goods and services - many legal systems have enacted legislation invalidating noassignment clauses on the ground that they interfere with factoring, the form of receivables financing whereby the promisor is notified of the assignment and is liable to suit by the financier. According to Tolhurst and Carter, judges themselves might have adopted this exception to freedom of contract due to its overwhelming popularity, ${ }^{93}$ and in Barbados Trust, Rix L.J. claimed that "it would be highly undesirable if customers could totally prevent their suppliers from factoring their book debts by the device of a non-assignment clause". ${ }^{94}$ In 2015, Parliament conferred on the government the power to make regulations on the subject, but it required the government to gain the approval of both Houses of Parliament. ${ }^{95}$ Eventually the Business Contract Terms (Assignment of Receivables) Regulations 2018 were approved by Parliament, but only after two previous versions of the Regulations had failed to gain Parliamentary approval. The Regulations frankly override freedom of contract; where they apply, they provide that a prohibition on assignment has "no effect". 96

What justifies overriding freedom of contract in this particular area? When first proposed, the Regulations were mostly supported with reference to a general argument that receivables financing is a valuable activity that should not be affected by freedom of contract. Writing in support of the legislative change, Beale, Gullifer, and Paterson presented evidence from surveys that non-assignment clauses hindered receivables financing, especially factoring. ${ }^{97}$ That is not surprising, given that the very purpose of a non-assignment clause is to prevent factoring. In a previous consultation exercise that contained a plan to invalidate non-assignment clauses, the Law

\footnotetext{
93 Tolhurst and Carter, "Prohibitions on Assignment", at p. 422.

94 Barbados Trust [2007] EWCA (Civ) 148, at [118].

95 Small Business, Enterprise and Employment Act 2015, s 161.

96 Business Contract Terms (Assignment of Receivables) Regulations 2018, r. 2(1).

${ }^{97}$ Beale, Gullifer, and Paterson, “A Case for Interfering with Freedom of Contract?”, p. 229.
} 
Commission noted that though the proposal was "controversial", ${ }^{98}$ there was "strong support from the [factoring and discounting] industry" 99 and that "receivables financiers think it important that prohibitions on assignment of a receivable should no longer be effective against the assignee". 100 Receivables financiers have every reason to support a legislative windfall, but that is not a sufficient reason to give them one. The mere fact that such clauses make receivables financing more difficult cannot be sufficient justification for the Regulations; we need a reason to promote receivables financing at the expense of the legitimate reasons businesses have for including non-assignment clauses in their contracts. ${ }^{101}$ Beale, Gullifer, and Paterson concluded that non-assignment clauses "seem to have an effect on receivables financing that is out of proportion to the benefits that the [nonassignment clause] will bring to the customer". ${ }^{102}$ Again, however, the law does not generally seek to assess the proportionality of a contract term's effect on markets.

As an alternative justification to the general argument in favour of financing, the proponents of legislative change made a more specific and more convincing claim: that the reform would help small businesses to gain access to finance by permitting them to factor their claims for payment even if they had agreed not to do so. Protecting small-business supplierpromisees against the bargaining power of large-business customerpromisors does, in principle, provide a valid reason to limit the effectiveness of non-assignment clauses. But the desire to protect small businesses was a poor fit as a justification for the Regulations in their initial form. As presented to Parliament the first and second times, the Regulations rendered void contractual attempts to restrict assignment of receivables in general, without regard to any indicator of inequality of bargaining power between the parties. ${ }^{103}$ They would have applied even where the contract was between two large businesses, and even to cases where a corporate-

98 Law Commission of England and Wales, Company Security Interests, No. 296 (2005), at [4.38].

99 Ibid., at [2.35].

100 Ibid., at [2.38].

101 Beale, Gullifer and Paterson did interview two customers, who explained that the purposes of non-assignment clauses were related to "first, practical issues over incorrect invoices and, secondly, to the commercial relationship between the parties". "A Case for Interfering with Freedom of Contract?", at pp. 221-22.

102 Ibid., at p. 229.

103 See Draft Business Contract Terms (Assignment of Receivables) Regulations 2015; Draft Business Contract Terms (Assignment of Receivables) Regulations 2017. 
behemoth promisee had agreed to forego assignment in a contract with a small-business promisor. The good faith of those commercial law academics who supported the Regulations is unquestionable. But one suspects that the reason this particular reform was given Parliamentary time was the desire of those engaged in factoring to increase their profits by amending other people's contracts through their lobbying efforts. The failure to tailor the Regulations to cases of unequal bargaining power appears to have been among the reasons that the first two versions failed to receive Parliamentary approval. ${ }^{104}$

The final version of the Regulations is more closely aligned with the goal of protecting small businesses with inadequate bargaining power. By way of contrast with the Unfair Contract Terms Act 1977, however, the Regulations make no attempt to decide the reasonableness of a nonassignment clause on a case-by-case basis. The Regulations are instead disapplied where the promisee is a "large business", ${ }^{105}$ which means that it must not be a small or medium business under the Companies Act's accounting regime. Additionally, certain contracts are excluded from the operation of the regulations, and some of these contracts (derivatives contracts, for example) are likely to involve sophisticated promisees who do not need legislative protection. ${ }^{106}$

It makes sense to draw sharp, clearly-administrable lines between cases where the Regulations apply and cases where they do not. The Regulations, however, still seem overbroad when compared with the small-businessprotective purpose that justifies them. A medium business is one that meets two of the following characteristics: (i) a turnover of not more than $£ 36$ million; (ii) a balance sheet of not more than $£ 18$ million; (iii) no more than 250 employees. ${ }^{107}$ Many fairly large businesses will still be able to invoke the regulations. Moreover, there is no attempt to calibrate their application according to whether the customer is a large or a small business. As a result, the Regulations will invalidate large numbers of unproblematic non-

104 See Mayer Brown, "Withdrawal of Draft Regulations on Contractual Terms with Respect to Assignment of Receivables" (1 ${ }^{\text {st }}$ Dec. 2017). For the City of London Law Society's hostile response to the first draft of the regulations, see R. Calnan, "Ban the Ban: Prohibiting Restrictions on the Assignment of Receivables" [2015] J.I.B.F.L. 136.

105 Business Contract Terms (Assignment of Receivables) Regulations 2018 r. 3. Regulation 3 also exempts cases where the supplier is a "special purpose vehicle".

106 Day, "Non-Assignment Clauses", at p. 208, notes that "a cynic might decry the power of special interest lobbying". His remark appears to be directed at the decision to exempt various classes of contract from the Regulations, but a thoroughgoing cynic might think something similar about the Regulations themselves.

107 Companies Act 2006, s.465. 
assignment clauses alongside the problematic ones they are aimed at invalidating.

\section{B. Unless Otherwise Agreed, Debt Claims are Assignable without Limitation}

The law's overall preference for assignability, especially when it comes to debt claims, also manifests itself in the default rules courts apply when the parties have not addressed assignability. The general rule is that contractual rights are assignable in the absence of a contractual restriction. While the law does make an exception to the assignability default for rights assumed to be personal, that category is small. Assignment is in theory limited to "cases where it can make no difference to the person on whom the obligation lies to which of two persons he is to discharge it". ${ }^{108}$ But where the promisor's obligation is to pay money, the promisee's right is considered impersonal and the identity of the right-holder is deemed irrelevant. "The reason that the debtor's consent is not required to an assignment of a debt is that the assignment cannot prejudice him". ${ }^{109}$

In practice, however, as cases like Barbados Trust illustrate, the rightholder's identity often makes all the difference. Non-assignment clauses are so common in contracts that there might be a strong case for reversing the general default rule to one of non-assignability, with limited exceptions for impersonal contractual rights. In some contexts, assignability might be so obviously contemplated that it should not be necessary to state it explicitly. In other cases, would it be too much to ask a party who wishes to have the power to transfer her rights unilaterally to bargain for it explicitly?

If it seems too radical a step to reverse the default rule, we might at least blunt its sharpest edges. Perhaps the most egregious example of the assignability default's tendency to overreach is Fitzroy v. Cave. ${ }^{110}$ Fitzroy and Cave were directors of a company; Cave was also the local manager. Fitzroy was unhappy with the way Cave was running the business and wanted to remove him from his managerial position. He set about trying to drive Cave into bankruptcy to disqualify him from serving as a director. Having discovered that Cave owed money to tradesmen who had supplied goods to him, Fitzroy approached the tradesmen and offered them a deal they couldn't refuse: if they would assign their claims against Cave to Fitzroy, Fitzroy would remit the proceeds to the tradesmen.

\footnotetext{
108 Tolhurst [1902] 2 K.B., at 668.

${ }^{109}$ Mulkerrins [2003] UKHL 41, [2003] 1 W.L.R. 1937, at [15], per Lord Millett.

110 [1905] 2 K.B. 364.
} 
Under cross-examination, Fitzroy admitted that making Cave a bankrupt was his "sole object" in taking the assignments. ${ }^{111}$ The Court of Appeal, however, found the assignments valid. Collins M.R. was reluctant but felt bound by the prior Court of Appeal decision in Comfort v. Betts, ${ }^{112}$ which had upheld assignments for the purpose of debt collection. Cozens-Hardy L.J. relied on the assumption that section 136 expands the range of assignable rights, but laid more stress on the idea that a debt claim is an item of property and must hence be transferable to anyone for any purpose. "I fail to see that we have anything to do with the motives which actuate the plaintiff, who is simply asserting a legal right consequential upon the possession of property which has been validly assigned to him". ${ }^{113}$ The decision was subjected to convincing contemporary criticism, ${ }^{114}$ but has since become well established.

The decision in Fitzroy illustrates not only the perils of affording talismanic status to the idea of property but also the dangers of treating assignability as a rule of law rather than as an implied term. The defendant's unsuccessful objection to the assignment in Fitzroy $v$. Cave was that it savoured of maintenance. But, in reality, that is not a powerful argument against an assignment. Treating assignability as a term of the contract, however, would have given Cave stronger ground to stand on. The contracts between Cave and the tradesman, presumably oral, said nothing about whether the tradesmen's claims to payment could be assigned. But the presumed intentions of Cave and the tradesmen could hardly have been to allow assignments of claims to Cave's worst enemy. Even if the assignability default remains intact, it would not be difficult to craft an exception to the assignability default for assignments taken solely for malicious purposes.

\section{Damages Claims are not Assignable Unless the Recipient Has a Particular Kind of Interest in Receiving the Transfer}

While overall the current law leans too heavily towards transferability, in one respect the law seems unreasonably hostile towards it. When it comes to assignments of rights to sue for unliquidated damages, English law continues to uphold the idea that a "bare" right to litigate cannot be assigned

\footnotetext{
111 Ibid., at 368.

112 [1891] 1 Q.B. 737.

113 Fitzroy v. Cave, [1905] 2 K.B., at p. 374.

114 P.H. Winfield, "Assignment of Choses in Action in Relation to Maintenance and Champerty” (1919) 35 L.Q.R. 143, 150-51.
} 
because the transaction savours of champerty and maintenance. But, as noted above, there is no special public policy reason to object to assignment of damages claims (just as there is no special public policy reason to insist on the assignability of debt claims). As Tettenborn has argued, it is difficult to understand both the scope of this rule and the reasons for it. ${ }^{115}$

The modern survival of this limitation on the validity of assignments was confirmed in Trendtex Trading Corp $v$ Credit Suisse. ${ }^{116}$ The case involved a claim arising out the Nigerian cement debacle of 1970s, when the government of Nigeria ordered too much cement and sought to avoid paying for much of it. Trendtex had agreed to sell 240,000 tons of cement; the Central Bank of Nigeria repudiated a letter of credit under which it had agreed to pay for the goods. Trendtex thus held a claim for damages - not for the agreed sum under the credit ${ }^{117}$ - and claimed that the damages amounted to \$14 million. But Trendtex needed help financing the litigation, which involved complex issues of sovereign immunity and doubts of over the proper jurisdiction in which to bring suit.

Credit Suisse had financed the transactions, and, given Trendtex's financial position, Credit Suisse had no hope of getting any of its money back unless Trendtex was able to make something of its right to sue the Central Bank of Nigeria. Under pressure from Credit Suisse, Trendtex agreed - in an agreement stated to be governed by Swiss law and Swiss jurisdiction - to sell its right to sue to the Central Bank of Nigeria to Credit Suisse for $\$ 800,000$. The agreement noted that an unnamed third party had agreed to buy the claim for $\$ 1.1$ million. Credit Suisse immediately sold the right to the mysterious third party for that price; through the efforts of Credit Suisse's lawyer, the mysterious third party settled the claim with the Central Bank of Nigeria for $\$ 8$ million, making a profit of $\$ 6.9$ million. Trendtex, on learning about what happened, felt that it had been tricked into parting with an asset for $10 \%$ of what it was worth. It sought to unwind the transaction and to sue in London rather than Switzerland. To avoid the exclusive jurisdiction clause in favour of the Swiss courts, Trendtex argued that the agreement to assign (including the exclusive jurisdiction clause) was void as against public policy.

The House of Lords ruled that the assignment was void. ${ }^{118}$ Lord Wilberforce said that an assignment to Credit Suisse alone would have been

\footnotetext{
115 Tettenborn, “Assignment of Rights to Compensation".

116 [1982] A.C. 679.

117 Ibid., at p. 694.

118 It left the issue of whether the assignment agreement as a whole was void to the Swiss courts.
} 
valid because Credit Suisse had a "genuine and substantial interest" in the sense that it legitimately wished to be paid what Trendtex owed it. ${ }^{119}$ Lord Roskill stated similarly that the question was whether Credit Suisse had a "genuine commercial interest in the enforcement of the claim of another". ${ }^{120}$ The problem, however, was that Credit Suisse was not motivated by its genuine commercial interest when it took the assignment; rather, it planned immediately to sell the claim to someone with no previous connection to the claim.

One difficulty with the law after Trendtex is that it is uncertain what counts as a legitimate commercial interest. ${ }^{121}$ But the more fundamental question is whether the maintenance-and-champerty doctrine provides any reason to invalidate assignments of otherwise-assignable rights. A particular problem with the current public policy rule is that it would seem to apply even if the parties to the contract had explicitly permitted assignability of an unliquidated claim for breach. Just as there is no general public policy reason to override no-assignment clauses, so there is also no public policy reason to override clauses affirmatively allowing assignability.

In truth, the real dispute in Trendtex had little to do with assignability. No objection to the assignment was raised by the promisor. The Central Bank of Nigeria had settled the case with the mysterious assignee. The dispute was instead between the promisee (Trendtex) and the initial assignee (Credit Suisse). Trendtex's real complaint was that Credit Suisse had committed fraud, duress, and/or breach of fiduciary duty in connection with the initial contract to assign; in short, it had been tricked or forced into parting with its right against the Central Bank of Nigeria for less than its real value. Trendtex's successful invocation of an illegality objection to the assignment was somewhat opportunistic; had Trendtex been given a larger share of the profit from the work of the mysterious assignee, it would not have complained.

Another sign that the champerty-and-maintenance limitation on assignability is on shaky ground is its inapplicability to debt claims. If the action in Trendtex had been for the agreed sum under the letter of credit as opposed to a damages claim, there would apparently have been no public policy problem with the assignment. The nineteenth-century case of Comfort $v$ Betts ruled that it was permissible for a debt collector-someone with no "genuine commercial interest" in the claim - to take an assignment

\footnotetext{
${ }^{119}$ Ibid.

${ }^{120}$ Ibid., at 703 .

${ }^{121}$ See Tettenborn, "Assignment of Rights to Compensation".
} 
of the debt and to split the proceeds of litigation with the assignor. ${ }^{122}$ In the later case of Laurent $v$ Sale \& Co. the court found that a similar arrangement was champertous. ${ }^{123}$ But that decision was an aberration, and the decision of the Court of Appeal in Camdex has made it clear that the assignment of a debt claim cannot be impugned on these grounds. ${ }^{124}$ This case involved the assignment of distressed debt to a "vulture fund". It was mentioned above for its approval both of the mistaken "debts as property" assumption and of the erroneous claim that statutory assignment is available in a broader set of circumstances than equitable assignment. Here, the main point about Camdex is that it is difficult to make understand why debt claims should be excluded from the purview of any champerty-and-maintenance limit on assignment. ${ }^{125}$ If the law were genuinely concerned about maintenance and champerty, it would similarly be concerned in cases like Camdex where it was evident from the moment of assignment that the assignee would need to bring litigation to assert the claim, and where the assignee had no prior interest in the dispute.

We should be careful, however, before completely jettisoning this line of cases. Though much refinement would be needed, it might just about be possible to recast the champerty-and-maintenance exception to assignability as a rough-and-ready default rule that attempts to reflect implied party intention to limit the circumstances in which assignment is permissible. Perhaps the parties to contracts, if they had time to fully specify their agreement, might often agree that bringing a third party into a dispute over an unliquidated damages claim is too conducive to the prolonging of the dispute to be worthwhile. Conversely, a better basis for the decision in Camdex might be that the parties to the original contract appear to have contemplated that the Bank of Zambia's debts were to be assignable; the written contract referred to the parties" "assigns". ${ }^{126}$

\footnotetext{
122 [1891] 1 Q.B. 737.

123 [1963] 1 W.L.R. 829.

124 Camdex [1998] 1 Q.B. 22. In Camdex, half-hearted attempts were made to distinguish Laurent $v$ Sale, but the judges failed actually to explain what divides the two cases. See Tettenborn, "Assignment of Rights to Compensation", p. 399 note 57.

125 The sharp distinction between the treatment of debt claims and damages in the law of assignability has long been criticised. Winfield, "Assignment of Choses in Action", pp. 150-51; Tettenborn, "Assignment of Rights to Compensation," pp. 399-400.

${ }^{126}$ Camdex [1998] Q.B., at 27.
} 


\section{CONCLUSION}

The English law of assignability of contractual rights is so deeply affected by unfounded assumptions that an entirely fresh start would be ideal. But it is unrealistic to expect judges to start from scratch. In the short term, we might hope to banish the faulty ideas criticised in Part II from debates over the future of assignability. Once these ideas have been rejected, a more convincing and coherent accommodation between assignability and nonassignability may emerge in time. Most importantly, judges and legislators should respect the sovereignty of the original parties to the contract over the issue of assignability, except where a demonstrable problem of inequality between those parties demands the law's intervention. 